\title{
THE USE OF PHOSPHATE SOLUBILIZING BACTERIA, PHOSPHATE SOURCES AND ANTIOXIDANTS FOR IMPROVING FRUIT QUALITY OF EARLIGRANDE PEACH TREES
}

\author{
Dina. A. E., M. M. Sourour ${ }^{1}$, M. D. El-Deeb ${ }^{1}$ and M. A. Nasr ${ }^{2}$ \\ 1. Dept. of Plant Prod., Faculty of Environ. Agri. Sc., Suez Canal Univ., Egypt. \\ 2. Dept. of Soil and Water, Faculty of Environ. Agri. Sc., Suez Canal Univ., Egypt.
}

\begin{abstract}
This work was carried out during the two seasons of 2009 and 2010 to study the effect of phosphate solubilizing bacteria (Enterobacter aerogenes ECu3, Bacillus subtilis $\mathrm{AC}_{2}$ and Enterobacter aerogenes $\mathrm{ECu}_{3} \times$ Bacillus subtilis $\mathrm{AC}_{2}$ ) and some phosphorus resources (rock phosphate, phosphoric acid, pentoxide phosphate and super phosphate) under foliar application of antioxidants (Ascorbic acid, vitamin E, and aqueous extract of Hibiscus sabdariffa) on fruit quality of EarliGrande peach trees at private Farm of El-Kharafeen region, North Sinai Governorate, Egypt. Results proved that all physical and chemical fruit parameters of treated trees with Bacillus subtilis $\mathrm{AC}_{2}$ under spraying aqueous extract of Hibiscus sabdariffa were significantly increased. All phosphate fertilization sources markedly affected fruit parameters of EarliGrande peach trees. Generally, the highest values of fruit parameters were found with the interaction between phosphoric acid and spraying H.sabdariffa extract. As for yield, fruit yield was significantly increased as phosphate solubilizing bacteria were applied. Bacillus subtilis $\mathrm{AC}_{2}$ spraying under aqueous extract of Hibiscus sabdariffa treatment recorded the highest yield compared with the remained treatments. At the same time treated trees with pentoxide phosphate and / or phosphoric acid under spraying $H$. sabdariffa and vitamin $\mathrm{C}$ extracts produced high values of fruit yield. Whereas, the interaction between $E$. aerogenes $x$ B. subtilis with spraying Vitamin $\mathrm{C}$ produced lowest values of acidity and highest values of vitamin $\mathrm{C}$ content. Bacillus subtilis $\mathrm{AC}_{2}$ under spraying aqueous extract of Hibiscus sabdariffa treatment recorded the highest values of T.S.S and moisture content in both seasons.
\end{abstract}

Key words: Prunus persica L.-phosphate sources- phosphate solubilizing bacteria- antioxidant materials.

\section{INTRODUCTION}

Peach tree (Prunus persica L.) is one of the most important deciduous fruits grown in Egypt successfully and are widespread in the newly reclaimed areas in Egypt. Most of these soil was considered calcareous. This type of soil has its own problems as an excess of $\mathrm{CaCO}_{3}$ and high $\mathrm{pH}$ value that cause a precipitation of mineral contents in an unavailable form for plants. Among of methods followed for improving the quantity and quality of peach trees is the application of major fertilizers to satisfy the needs of plant from such elements, since good growth is mostly associated with good yield. Phosphorus is a very important nutrient for crop growth and high yield with good quality. 
It plays a key role in the metabolic process of the conversion of sugar into starch and cellulose. Sandy soils may have some nutrient problems such as less fertility in general and less availability of some elements including phosphorus in case of high $\mathrm{pH}$ value.Yield and its components showed a positive response to phosphorus fertilizers. Papplications have increased flower formation, whereas, $\mathrm{N}$ was found to reduce it (Chatzitheodorou et al., 2004).

Yield and fruit weight of peach fruits increased with increasing the rate of $\mathrm{P}$ application up to 700g.tree ${ }^{-1}$ (Awasthi et al., 1998). Many soil fungi and bacteria can solubilize inorganic phosphates (Asea et al. 1988; Singh and Sharma 1993).

Phosphate solubilizing microorganisms (PSMs) play an important role in supplementing phosphorus to the plants, allowing a sustainable use of phosphate fertilizers (Gyaneshwar et al. 1998; Samah, 2002). Application of (PSMs) in the field has been reported to increase mycorrhiza development (Toro et al. 1997 Ivanova et al., 2006). The goal of this study was examining the possibility of replacing chemical fertilizers partially by using phosphate solubilizing bacteria and antioxidant applications to improve fruit quality and total yield of EarliGrande peach trees.

\section{MATERIALS AND METHODS}

This study was carried out during 2009 and 2010 seasons on seventy-two uniform in vigour of about thirteen years old EarliGrande peach trees budded onto bitter almond rootstock grown in a private peach orchard located at El-Kharafen in Rafah District, North Sinai Governorate, Egypt. The trees were planted at $5 \times 5 \mathrm{~m}$ apart and growing in sandy soil depending on rainfall irrigation. Analysis of the soil samples are shown in Table (1) according to (Piper, 1947).
The experiment included five phosphate source treatment combinations which were: Control, rock phosphate alone $(29 \% \pm 5 \%)$ $\left(400\right.$ g.tree $\left.{ }^{-1}\right)$, phosphoric acid (85\%) $(150$ $\mathrm{cm} . \mathrm{m}^{-3}$ water), pentoxide phosphate (150 $\mathrm{cm}$. $\mathrm{zm}^{-3}$ water) and calcium super phosphate (16-18\%) (400g.tree $\left.{ }^{-1}\right)$.The strains were isolated and identified by Abd El-Azeem (2006).

Different Phosphorous sources were sprayed in three stages: the first application was applied after the first contract before flowering, the second was applied during fruit-set, and the third one was applied two weeks before harvest.

While, super phosphate and Rock phosphate were added on the beginning of January (In the winter). In addition, three Phosphate solubilizing bacteria treatments were applied i.e., Enterobacter aerogenes $\mathrm{ECu}_{3}{ }^{+}$Rock phosphate, Bacillus subtilis $\mathrm{AC}_{2}{ }^{+}$Rock phosphate and (Enterobacter aerogenes $\mathrm{ECu}_{3}$ X Bacillus subtilis $\mathrm{AC}_{2}$ ). All solubilizing bacteria were added $(200 \mathrm{ml})$ with $400 \mathrm{~g}$ of rock phosphate per tree.

Three antioxidant applications were sprayed (Ascorbic acid "V.C" about 100200 ppm, Tocopherol "V.E" about 0.1-0.3 ppm and aqueous extract of Hibiscus sabdariffa at concentration about $125 \mathrm{~g}$. litre $^{-1}$. All antioxidant applications were sprayed three times after fruit set stage and until pre-harvest.

\section{Measurements of fruit quality:}

Ten fruits from each treatment were collected and transferred to the laboratory, and used for the following measurements: Fruit size, fruit length, diameter, fruit weight, fruit size and firmness. Fruit juice was obtained individually by pressing the fruit flesh through doubled gauze. Total soluble solid (TSS) concentration was measured using a hand-held refractometer.

The total acidity was calculated by titrating $10 \mathrm{ml}$ of juice with $\mathrm{NaOH} 0.1$ 
Table (1): Soil physical and chemical analyses at depth $(0-45 \mathrm{~cm})$ from the soil surface for the peach orchard at Rafah District in North Sinai Governorate, Egypt.

\begin{tabular}{|c|c|c|c|c|c|c|c|c|c|c|c|c|c|c|}
\hline \multirow{3}{*}{$\begin{array}{c}\text { Soil } \\
\text { Sample } \\
\text { depth } \\
\text { (cm) }\end{array}$} & \multicolumn{4}{|c|}{ Physical analysis } & \multirow{3}{*}{$\begin{array}{c}\text { E.C } \\
\left.\text { dS.m }{ }^{-1}\right)\end{array}$} & \multirow[t]{3}{*}{ pH } & \multicolumn{8}{|c|}{ Chemical analysis } \\
\hline & \multirow{2}{*}{ 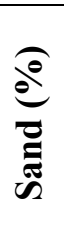 } & \multirow{2}{*}{ 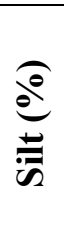 } & \multirow{2}{*}{$\underbrace{\frac{a}{0}}_{\frac{a}{0}}$} & \multirow{2}{*}{ 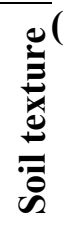 } & & & \multicolumn{4}{|c|}{ Cations (meq. $\mathrm{l}^{-1}$ ) } & \multicolumn{4}{|c|}{ Anions (meq..$^{-1}$ ) } \\
\hline & & & & & & & ${ }^{\ddagger}$ & ${ }^{+}{ }^{+}$ & ${ }^{+}$ & \pm & 's & $\underset{\underbrace{}}{0}$ & $\bar{U}$ & 'రి \\
\hline$\stackrel{10}{\stackrel{1}{0}}$ & ڤேं & $\underset{\sim}{\sim}$ & ळ) & 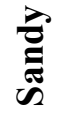 & $\stackrel{\mathbb{t}}{\stackrel{+}{0}}$ & ল্. & $\bar{i}$ & $\stackrel{\infty}{\text { ִׁ }}$ & 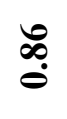 & m̧ & ' & 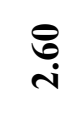 & 更 & 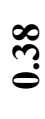 \\
\hline
\end{tabular}

mol.1 ${ }^{-1}$ to $\mathrm{pH} 8.2$ and expressed as malic acid equivalent (AOAC., 1990).

\section{Statistical analysis:}

The results in the first stage were exposed to proper statistical analysis of variance for a randomized complete block design (two factors) using MSTATC computer program (Russell, 1986) with three replicates and each replicate was represented by two trees. Duncan's multiple range tests was used for comparison between means. Different alphabetical letters in the same column are significantly differed at (0.05) level of significance (Duncan, 1955).

\section{RESULTS AND DISCUSSION}

\section{Fruit physical parameters:}

\subsection{Fruit length:}

Table (2) clears that treated trees with Bacillus subtilis $\mathrm{AC}_{2}$ and sprayed with $H$. sabdariffa extract gave the highest increase in fruit length $(5.77$ and $5.88 \mathrm{~cm})$ in both seasons. While, the least ones were observed in the interaction between Enterobacter aerogenes ECu $u_{3}$ and vitamin $\mathrm{E}$, The other interaction effects came in between.

Also, the interaction effect between phosphate sources and antioxidant applications ycted significantly on fruit length which ranged from (4.64 to
$6.19 \mathrm{~cm})$ in the first season and from $(4.83$ to $6.25 \mathrm{~cm}$ ) in the second one.

The highest values of fruit length were found with the interaction between phosphoric acid and spraying with $H$. sabdariffa extract (6.19 \& 6.25\%). While, the least ones were recorded with untreated trees (control) $(4.64 \& 4.83 \mathrm{~cm})$ in two seasons. The other interaction came in between.

\subsection{Fruit width:}

As for the interaction, the effect between phosphate solubilizing bacteria and antioxidant treatments, data in Table (2) shows that treated trees with Bacillus subtilis $\mathrm{AC}_{2}$ and sprayed with $H$. sabdariffa extract gave the highest increment in fruit width $(5.70$ and $5.72 \mathrm{~cm})$. While, the least ones were found with Enterobacter aerogenes $E C u_{3}$ and Vitamin $\mathrm{E}$ treatment, in both seasons. Concerning, the interaction effect between phosphate sources and antioxidant applications, treated trees with phosphoric acid and sprayed with $H$. sabdariffa extract proved to be the most effective treatment of fruit wide in the first season. While, treated trees with pentoxide phosphate and sprayed with H.sabdariffa extract gave the highest values in second season. On the other hand, the least ones were given in control treatment, during both seasons. The other treatments came in between. 
Table (2):Effect of phosphate resources and/or phosphate solubilizing bacteria under antioxidant applications on fruit length, fruit width and shape index of 'EarliGrande' peach trees during 2009 and 2010 seasons.

\begin{tabular}{|c|c|c|c|c|c|c|c|}
\hline \multirow[t]{2}{*}{ Treatment } & \multirow[t]{2}{*}{$\begin{array}{l}\text { Antioxidant } \\
\text { application }\end{array}$} & \multicolumn{2}{|c|}{$\begin{array}{l}\text { Fruit length } \\
\text { (cm) }\end{array}$} & \multicolumn{2}{|c|}{$\begin{array}{l}\text { Fruit width } \\
\text { (cm) }\end{array}$} & \multicolumn{2}{|c|}{$\begin{array}{c}\text { Shape index } \\
(\mathrm{L} / \mathrm{W})\end{array}$} \\
\hline & & 2009 & 2010 & 2009 & 2010 & 2009 & 2010 \\
\hline \multicolumn{8}{|c|}{ 1. Effect of phosphate solubilizing bacteria and antioxidants application } \\
\hline \multirow[t]{3}{*}{ E. aerogenes } & $\begin{array}{l}\text { Hibiscus } \\
\text { sabdariffa } *\end{array}$ & $5.64^{\mathrm{abc}}$ & $5.77^{\mathrm{ab}}$ & $5.28^{\mathrm{bcd}}$ & $5.55^{b}$ & $1.07^{\mathrm{a}}$ & $1.04^{\mathrm{a}}$ \\
\hline & Vitamin $\mathbf{C}$. & $5.44^{\text {bcd }}$ & $5.55^{\mathrm{cd}}$ & $5.25^{\mathrm{cd}}$ & $5.38^{\mathrm{bc}}$ & $1.04^{\mathrm{a}}$ & $1.03^{\mathrm{a}}$ \\
\hline & Vitamin E. & $5.06^{\mathrm{d}}$ & $5.17^{\mathrm{e}}$ & $5.04^{\mathrm{e}}$ & $4.82^{\mathrm{d}}$ & $1.00^{\mathrm{a}}$ & $1.07^{\mathrm{a}}$ \\
\hline \multirow[t]{3}{*}{ B. subtilis } & $\begin{array}{l}\text { Hibiscus } \\
\text { sabdariffa }\end{array}$ & $5.77^{\mathrm{a}}$ & $5.88^{\mathrm{a}}$ & $5.70^{\mathrm{a}}$ & $5.72^{\mathrm{a}}$ & $1.0^{\mathrm{a}}$ & $1.03^{\mathrm{a}}$ \\
\hline & Vitamin C. & $5.66^{\mathrm{ab}}$ & $5.70^{a b c}$ & $5.37^{\mathrm{bc}}$ & $5.35^{\mathrm{bc}}$ & $1.05^{\mathrm{a}}$ & $1.07^{\mathrm{a}}$ \\
\hline & Vitamin E. & $5.37^{\mathrm{cd}}$ & $5.45^{\mathrm{d}}$ & $5.11^{\mathrm{de}}$ & $5.20^{\mathrm{c}}$ & $1.05^{\mathrm{a}}$ & $1.05^{\mathrm{a}}$ \\
\hline \multirow{3}{*}{$\begin{array}{l}\text { E. aerogenes } x \\
\text { B. subtilis }\end{array}$} & Hibiscus & $5.67^{\mathrm{ab}}$ & $5.71^{\mathrm{abc}}$ & $5.40^{\mathrm{b}}$ & $5.53^{\mathrm{b}}$ & $1.05^{\mathrm{a}}$ & $1.03^{\mathrm{a}}$ \\
\hline & $\begin{array}{l}\text { sabdariffa } \\
\text { Vitamin C. }\end{array}$ & $5.45^{\text {bcd }}$ & $5.63^{\mathrm{bcd}}$ & $5.60^{\mathrm{ab}}$ & $5.54^{\mathrm{b}}$ & $0.97^{\mathrm{a}}$ & $1.02^{\mathrm{a}}$ \\
\hline & Vitamin E. & $5.51^{\mathrm{bc}}$ & $5.68^{\mathrm{bc}}$ & $5.19^{\mathrm{d}}$ & $5.37^{\mathrm{bc}}$ & $1.06^{\mathrm{a}}$ & $1.06^{\mathrm{a}}$ \\
\hline
\end{tabular}

2. Effect of phosphate recourses and antioxidants application

\begin{tabular}{|c|c|c|c|c|c|c|c|}
\hline \multirow[t]{3}{*}{ Control } & Hibiscus & $4.913^{\mathrm{fg}}$ & $5.267^{\mathrm{fg}}$ & $4.550^{\mathrm{fg}}$ & $5.563^{\mathrm{abc}}$ & $1.080^{\mathrm{a}-\mathrm{d}}$ & $0.9467^{b}$ \\
\hline & $\begin{array}{l}\text { sabaarıJJa } \\
\text { Vitamin C. }\end{array}$ & $4.840^{\mathrm{fg}}$ & $4.977^{\text {gh }}$ & $4.763^{\mathrm{ef}}$ & $4.690^{\mathrm{d}}$ & $1.027^{\mathrm{d}}$ & $1.060^{\mathrm{a}}$ \\
\hline & Vitamin E. & $4.647^{\mathrm{g}}$ & $4.837^{\mathrm{h}}$ & $4.310 \mathrm{~g}$ & $4.943^{\mathrm{cd}}$ & $1.077^{\mathrm{a}-\mathrm{d}}$ & $0.9800^{\mathrm{ab}}$ \\
\hline \multirow{3}{*}{$\begin{array}{l}\text { Rock } \\
\text { Phosphate }\end{array}$} & Hibiscus & $5.590^{\mathrm{cd}}$ & $5.900^{\text {bcd }}$ & $5.013^{\mathrm{b}-\mathrm{e}}$ & $5.580^{\mathrm{abc}}$ & $1.113^{\mathrm{a}-\mathrm{d}}$ & $1.057^{\mathrm{ab}}$ \\
\hline & $\begin{array}{l}\text { sabdariffa } \\
\text { Vitamin C. }\end{array}$ & $5.290^{\mathrm{c}-\mathrm{f}}$ & $5.667^{\mathrm{de}}$ & $4.960^{\text {cde }}$ & $5.357^{\mathrm{a}-\mathrm{d}}$ & $1.067^{\mathrm{a}-\mathrm{d}}$ & $1.057^{\mathrm{ab}}$ \\
\hline & Vitamin E. & $5.103^{\mathrm{d}-\mathrm{g}}$ & $5.460^{\text {ef }}$ & $4.870^{\mathrm{cf}}$ & $5.397^{\mathrm{abc}}$ & $1.050^{\mathrm{a}-\mathrm{d}}$ & $1.013^{\mathrm{ab}}$ \\
\hline \multirow[t]{2}{*}{$\begin{array}{l}\text { Super } \\
\text { phosphate }\end{array}$} & $\begin{array}{l}\text { Hibiscus } \\
\text { sabdariffa }\end{array}$ & $5.463^{\text {cde }}$ & $5.967^{\mathrm{a}-\mathrm{d}}$ & $4.850^{\text {def }}$ & $5.750^{\mathrm{ab}}$ & $1.127^{\mathrm{abc}}$ & $1.037^{\mathrm{ab}}$ \\
\hline & Vitamin C. & $4.997^{\text {efg }}$ & $5.810^{\mathrm{cd}}$ & $4.677^{\mathrm{efg}}$ & $5.617^{\mathrm{abc}}$ & $1.070^{\mathrm{a}-\mathrm{d}}$ & $1.033^{\mathrm{ab}}$ \\
\hline \multirow[t]{3}{*}{$\begin{array}{l}\text { Pentoxide } \\
\text { phosphate }\end{array}$} & $\begin{array}{l}\text { Vitamin E. } \\
\text { Hibiscus } \\
\text { sabdariffa }\end{array}$ & $\begin{array}{l}4.993^{\mathrm{eg}} \\
6.107^{\mathrm{ab}}\end{array}$ & $\begin{array}{l}5.307^{\mathrm{f}} \\
6.197^{\mathrm{ab}}\end{array}$ & $\begin{array}{l}4.813^{\mathrm{def}} \\
5.420^{\mathrm{a}}\end{array}$ & $\begin{array}{l}5.113^{\mathrm{bcd}} \\
5.980^{\mathrm{a}}\end{array}$ & $\begin{array}{l}1.040^{\mathrm{bcd}} \\
1.127^{\mathrm{abc}}\end{array}$ & $\begin{array}{l}1.040^{\mathrm{ab}} \\
1.037^{\mathrm{ab}}\end{array}$ \\
\hline & Vitamin C. & $5.470^{\text {cde }}$ & $5.937^{\mathrm{a}-\mathrm{d}}$ & $5.260^{\mathrm{abc}}$ & $5.757^{\mathrm{ab}}$ & $1.037^{\mathrm{cd}}$ & $1.033^{\mathrm{ab}}$ \\
\hline & Vitamin E. & $5.660^{\mathrm{bc}}$ & $5.777^{\text {cd }}$ & $5.193^{\mathrm{a}-\mathrm{d}}$ & $5.430^{a b c}$ & $1.090^{\mathrm{a}-\mathrm{d}}$ & $1.063^{\mathrm{a}}$ \\
\hline \multirow{3}{*}{$\begin{array}{l}\text { Phosphoric } \\
\text { Acid }\end{array}$} & Hibiscus & $6.190^{\mathrm{a}}$ & $6.25^{\mathrm{a}}$ & $5.527^{\mathrm{a}}$ & $5.977^{\mathrm{a}}$ & $1.120^{\mathrm{abc}}$ & $1.047^{\mathrm{ab}}$ \\
\hline & Vitamin C. & $6.150^{\mathrm{a}}$ & $6.177^{\mathrm{ab}}$ & $5.437^{\mathrm{a}}$ & $5.820^{\mathrm{a}}$ & $1.130^{\mathrm{ab}}$ & $1.063^{\mathrm{a}}$ \\
\hline & Vitamin E. & $6.077^{\mathrm{ab}}$ & $6.013^{\mathrm{abc}}$ & $5.360^{\mathrm{ab}}$ & $5.593^{b c}$ & $1.133^{\mathrm{a}}$ & $1.077^{\mathrm{a}}$ \\
\hline
\end{tabular}

Means followed by the same letter (s) within each column are not significantly different at the 0.05 level, according to Duncan's multiple range test.

* Aqueous extract of Roselle plant Hibiscus sabdariffa. 


\subsection{Shape index:}

Data in Table (2) revealed that all treatment gave the similar effect in shape index in both seasons. Concerning, the interaction effect between phosphate sources and antioxidant applications, the interaction effect between phosphoric acid and sprayed with $H$. sabdariffa extract, gave the highest values of shape index (1.133 and 1.077). While, the least ones were given in control treatment in both seasons.

\subsection{Fruit volume:}

Table (3) show that treated trees with Bacillus subtilis $\mathrm{AC}_{2}$ and sprayed with H.sabdariffa extract gave the highest increase in fruit volume (74.47 and 79.07 $\mathrm{cm}^{3}$ ) in both seasons. While, the least ones were found with Enterobacter aerogenes $\mathrm{ECu}_{3}$ strain and Vitamin E. Regarding, the interaction effect between phosphate sources and antioxidant applications, data in Table (3) shows that the interaction effect between phosphoric acid and sprayed with $H$. sabdariffa extract, caused high significant increase of fruit volume (73.97 and $111.5 \mathrm{~cm}^{3}$ ). While, the least ones were observed in control treatment, during both seasons.

\subsection{Fruit weight:}

The interaction effect between rock phosphate, phosphate solubilizing bacteria and antioxidant treatments, is shown in Table (3). Data revealed that treated trees with rock phosphate, Bacillus subtilis $\mathrm{AC}_{2}$ and sprayed with H.sabdariffa extract gave the highest increase in fruit weight in both seasons. While, the least ones were obtained with the interactions between rock phosphate with Enterobacter aerogenes $\mathrm{ECu}_{3}$ and Vitamin $\mathrm{E}$ in fruit weight in both seasons. The remained interactions treatment came in between. As for the interaction effect between phosphate sources and antioxidant applications, Table (3) shows that the highest value of fruit weight were observed in the interaction effect between phosphoric acid and sprayed with $H$. sabdariffa extract in both seasons. While, in both seasons the least ones were given in control treatment.

The remained treatments came in between. Sahain et al. (2007) mentioned that EM (a commercial Biostimulant) containing more than 60 selected strains more effective on fruit quality i.e., fruit weight, their dimensions, total sugars (\%) and TSS (\%) at harvest compared to the control on apple fruits. on the other hand Yang Sheng (2010) who demonstrated that after compound bio-fertilizer enrichment, fruit number per tree, weight per fruit and average yield per tree were all improved obviously in peach trees. Similar observations were reported by $\mathbf{L i}$ et al., (2007). Who reported that spraying with $\mathrm{KH}_{2} \mathrm{PO}_{4}$ improved fruit quality parameters on 4 peach cultivars.

The increase in fruit weight, length, width, and size might be attributed to the increase in cell division and cell elongation caused by auxins and some antioxidants. In addition, ascorbic and citric acids as natural organic antioxidant compounds have an auxinic action and synergistic effect on improving fruit size and weight (Kassem et al., 2010). These results are in line with the findings of Claudia et al. (2012) who reported that Roselle (Hibiscus sabdariffa L.) extracts contain anthocyanin and ascorbic acid and some active antioxidants.

\subsection{Total yield:}

With regard to the interaction effect between rock phosphate, phosphate solubilizing bacteria and antioxidant treatments, Table (3) show that Rock phosphate with adding Bacillus subtilis $\mathrm{AC}_{2}$ and sprayed with H.sabdariffa extract proved to be the most effective treatment in total yield $\left(50.03\right.$ and $55.12 \mathrm{Kg}$. tree $\left.^{-1}\right)$ in both seasons. 
Table (3):Effect of phosphate sources and/or phosphate solubilizing bacteria under antioxidant applications on fruit volume, fruit weight, total yield and fruit firmness of 'EarliGrande' peach trees during 2009 and 2010 seasons.

\begin{tabular}{|c|c|c|c|c|c|c|c|c|c|}
\hline \multirow[t]{2}{*}{ Treatment } & \multirow[t]{2}{*}{$\begin{array}{l}\text { Antioxidant } \\
\text { application }\end{array}$} & \multicolumn{2}{|c|}{$\begin{array}{c}\text { Fruit volume } \\
\left(\mathrm{cm}^{3}\right)\end{array}$} & \multicolumn{2}{|c|}{$\begin{array}{c}\text { Fruit weight } \\
\text { (g) }\end{array}$} & \multicolumn{2}{|c|}{$\begin{array}{l}\text { Total yield } \\
\left(\text { Kg.tree }^{-1}\right)\end{array}$} & \multicolumn{2}{|c|}{ Fruit firmness } \\
\hline & & 2009 & 2010 & 2009 & 2010 & 2009 & 2010 & 2009 & 2010 \\
\hline & 1. Effect of $p$ & hate solu & lizing bac & eria and a & ioxidants & plication & & & \\
\hline \multirow[t]{3}{*}{ E. aerogenes } & $\begin{array}{c}\text { Hibiscus } \\
\text { sabdariffa * }\end{array}$ & $68.17^{\mathrm{ab}}$ & $75.42^{b}$ & $67.30^{\mathrm{b}}$ & $70.11^{\mathrm{e}}$ & $47.68^{b}$ & $51.42^{\mathrm{b}}$ & $3.41^{\text {bcd }}$ & $3.59^{\mathrm{bc}}$ \\
\hline & Vitamin $\mathrm{C}$. & $63.75^{\mathrm{bc}}$ & $65.58^{\mathrm{e}}$ & $62.71^{\mathrm{d}}$ & $71.99^{\mathrm{cd}}$ & $42.67^{\mathrm{cd}}$ & $48.88^{\mathrm{cd}}$ & $3.51^{\mathrm{abc}}$ & $3.70^{\mathrm{b}}$ \\
\hline & Vitamin E. & $54.08^{\mathrm{d}}$ & $63.13^{\mathrm{g}}$ & $55.25^{\mathrm{f}}$ & $68.27^{f}$ & $37.90^{\mathrm{f}}$ & $39.64^{f}$ & $3.26^{\mathrm{d}}$ & $3.26^{\mathrm{d}}$ \\
\hline \multirow[t]{3}{*}{ B. subtilis } & $\begin{array}{c}\text { Hibiscus } \\
\text { sabdariffa }\end{array}$ & $74.47 \mathrm{a}$ & $79.07^{\mathrm{a}}$ & $73.11^{\mathrm{a}}$ & $79.20^{\mathrm{a}}$ & $50.03^{\mathrm{a}}$ & $55.12^{\mathrm{a}}$ & $3.53^{\mathrm{ab}}$ & $3.98^{\mathrm{ab}}$ \\
\hline & Vitamin C. & $66.54^{\mathrm{abc}}$ & $75.38^{\mathrm{bc}}$ & $66.62^{\mathrm{bc}}$ & $76.58^{\mathrm{b}}$ & $43.20^{\mathrm{c}}$ & $51.13^{\mathrm{b}}$ & $3.73^{\mathrm{a}}$ & $4.15^{\mathrm{a}}$ \\
\hline & Vitamin E. & $59.80^{\text {bcd }}$ & $68.62^{\mathrm{d}}$ & $59.42^{\mathrm{e}}$ & $76.18^{\mathrm{bc}}$ & $41.29^{\mathrm{de}}$ & $47.25^{\mathrm{d}}$ & $3.28^{\mathrm{d}}$ & $3.57^{\mathrm{bc}}$ \\
\hline \multirow{5}{*}{$\begin{array}{l}\text { E. aerogenes } x \\
\text { B. subtilis }\end{array}$} & Hibiscus & $72.17^{\mathrm{a}}$ & $77.23^{\mathrm{ab}}$ & $71.26^{\mathrm{ab}}$ & $76.47^{\mathrm{b}}$ & $49.92^{\mathrm{a}}$ & $54.45^{\mathrm{ab}}$ & $3.46^{\text {abcd }}$ & $3.38^{\mathrm{cd}}$ \\
\hline & sabdariffa & & & & & & & & \\
\hline & Vitamin $\mathrm{C}$. & $66.29^{\mathrm{abc}}$ & $75.08^{c}$ & $64.92^{c}$ & $74.37^{\mathrm{c}}$ & $42.44^{\text {cde }}$ & $49.54^{\mathrm{c}}$ & $3.38 \mathrm{~cd}$ & $3.55^{\mathrm{bcd}}$ \\
\hline & Vitamin E. & $54.67^{\mathrm{cd}}$ & $64.65^{\mathrm{f}}$ & $59.74^{\mathrm{e}}$ & $71.3^{\mathrm{d}}$ & $40.4^{\mathrm{e}}$ & $45.67^{\mathrm{e}}$ & $2.92 \mathrm{e}$ & $3.01 \mathrm{e}$ \\
\hline & 2. Effect o & sphate so & rces and a & tioxidants & pplication & & & & \\
\hline \multirow[t]{3}{*}{ Control } & $\begin{array}{c}\text { Hibiscus } \\
\text { sabdariffa }\end{array}$ & $54.70^{\text {fgh }}$ & $51.80^{\mathrm{f}}$ & $51.77^{\mathrm{gh}}$ & $64.30^{\mathrm{e}}$ & $36.82^{\mathrm{e}}$ & $39.80^{\text {ef }}$ & $2.873^{\mathrm{efg}}$ & $3.310^{\mathrm{h}}$ \\
\hline & Vitamin C. & $51.17^{\text {gh }}$ & $49.57^{f}$ & $49.68^{\mathrm{gh}}$ & $63.48^{\mathrm{e}}$ & $36.83^{\mathrm{e}}$ & $45.30^{\mathrm{def}}$ & $2.900^{\mathrm{efg}}$ & $3.433^{\text {gh }}$ \\
\hline & Vitamin E. & $47.75^{\mathrm{h}}$ & $61.33^{\mathrm{ef}}$ & $44.87^{\mathrm{h}}$ & $55.76^{\mathrm{e}}$ & $35.13^{\mathrm{e}}$ & $38.90 \mathrm{f}$ & $2.643^{\mathrm{g}}$ & $3.457^{\text {gh }}$ \\
\hline \multirow{4}{*}{$\begin{array}{c}\text { Rock } \\
\text { Phosphate }\end{array}$} & Hibiscus & $60.67^{\mathrm{c}-\mathrm{f}}$ & $71.23^{\mathrm{cf}}$ & $66.63^{\text {bcd }}$ & $74.55^{\text {cde }}$ & $52.47^{\mathrm{a}-\mathrm{d}}$ & $57.86^{\mathrm{abc}}$ & $3.233^{\mathrm{c}-\mathrm{f}}$ & $4.030^{\mathrm{def}}$ \\
\hline & sabdariffa & & & & & & & & \\
\hline & Vitamin C. & $62.17^{\text {cde }}$ & $69.27^{\mathrm{c}-\mathrm{f}}$ & $63.10^{\text {cde }}$ & $68.35^{\mathrm{de}}$ & $42.97^{\mathrm{de}}$ & $46.58^{\mathrm{c}-\mathrm{f}}$ & $3.580^{\mathrm{abc}}$ & $4.140^{\text {cde }}$ \\
\hline & Vitamin E. & $51.00^{\mathrm{gh}}$ & $65.40^{\mathrm{def}}$ & $52.93^{\text {fgh }}$ & $74.1^{\text {cde }}$ & $42.72^{\mathrm{de}}$ & $44.75^{\mathrm{def}}$ & $2.797^{\mathrm{fg}}$ & $3.77^{\text {efg }}$ \\
\hline \multirow[t]{3}{*}{$\begin{array}{c}\text { Super } \\
\text { phosphate }\end{array}$} & $\begin{array}{c}\text { Hibiscus } \\
\text { sabdariffa }\end{array}$ & $57.77^{\mathrm{d}-\mathrm{g}}$ & $83.63^{\text {b-e }}$ & $59.42^{\mathrm{c}-\mathrm{g}}$ & $74.67^{\text {cde }}$ & $44.04^{\text {cde }}$ & $54.37^{\mathrm{a}-\mathrm{d}}$ & $3.203^{\mathrm{c}-\mathrm{f}}$ & $3.957 \mathrm{def}$ \\
\hline & Vitamin C. & $56.50^{\text {efg }}$ & $82.17^{\text {b-e }}$ & $55.95^{\mathrm{efg}}$ & $88.13^{\mathrm{abc}}$ & $52.85^{\mathrm{a}-\mathrm{d}}$ & $51.29^{\mathrm{a}-\mathrm{e}}$ & $3.593^{\mathrm{abc}}$ & $4.183^{\mathrm{bcd}}$ \\
\hline & Vitamin E. & $52.17^{\text {gh }}$ & $70.30^{\mathrm{c}-\mathrm{f}}$ & $56.89^{\mathrm{d}-\mathrm{g}}$ & $68.95^{\mathrm{de}}$ & $45.90^{\text {b-e }}$ & $48.86^{\mathrm{b}-\mathrm{f}}$ & $3.130^{\mathrm{def}}$ & $3.713^{\mathrm{fg}}$ \\
\hline \multirow[t]{3}{*}{$\begin{array}{l}\text { Pentoxide } \\
\text { phosphate }\end{array}$} & $\begin{array}{c}\text { Hibiscus } \\
\text { sabdariffa }\end{array}$ & $65.83^{\mathrm{bc}}$ & $101.1^{\mathrm{ab}}$ & $68.67^{\mathrm{bc}}$ & $96.76^{\mathrm{ab}}$ & $59.53^{\mathrm{a}}$ & $62.12^{\mathrm{a}}$ & $3.913^{\mathrm{a}}$ & $4.700^{\mathrm{a}}$ \\
\hline & Vitamin C. & $64.22^{\mathrm{cd}}$ & $83.50^{\text {b-e }}$ & $61.77^{\mathrm{c}-\mathrm{f}}$ & $91.00^{\mathrm{abc}}$ & $56.28^{\mathrm{ab}}$ & $61.23^{\mathrm{a}}$ & $3.973^{\mathrm{a}}$ & $4.873^{\mathrm{a}}$ \\
\hline & Vitamin E. & $53.00^{\text {gh }}$ & $95.67^{\mathrm{abc}}$ & $54.25^{\mathrm{e}-\mathrm{h}}$ & $84.40^{\text {bcd }}$ & $55.65^{\text {abc }}$ & $58.74^{\mathrm{ab}}$ & $3.450^{\text {bcd }}$ & $4.500^{\mathrm{abc}}$ \\
\hline \multirow{4}{*}{$\begin{array}{c}\text { Phosphoric } \\
\text { Acid }\end{array}$} & Hibiscus & $73.97^{\mathrm{a}}$ & $111.5^{\mathrm{a}}$ & $80.06^{\mathrm{a}}$ & $103.4^{\mathrm{a}}$ & $61.92^{\mathrm{a}}$ & $62.45^{\mathrm{a}}$ & $3.620^{\mathrm{abc}}$ & $4.573^{\mathrm{ab}}$ \\
\hline & sabdariffa & & & & & & & & \\
\hline & Vitamin C. & $71.67^{\mathrm{ab}}$ & $106.3^{\mathrm{ab}}$ & $74.23^{a b}$ & $99.10^{\mathrm{ab}}$ & $60.46^{\mathrm{a}}$ & $62.22^{\mathrm{a}}$ & $3.710^{\mathrm{ab}}$ & $4.693^{\mathrm{a}}$ \\
\hline & Vitamin E. & $64.67^{\mathrm{cd}}$ & $90.67^{\mathrm{a}-\mathrm{d}}$ & $68.48^{\mathrm{bc}}$ & $92.52^{\mathrm{abc}}$ & $58.77^{\mathrm{a}}$ & $59.80^{\mathrm{ab}}$ & $3.310^{\mathrm{b}-\mathrm{e}}$ & $4.223^{\mathrm{bcd}}$ \\
\hline
\end{tabular}

\subsection{Fruit firmness:}

As for the interaction effect between rock phosphate, phosphate solubilizing bacteria and antioxidant treatments, Table (3) reveals that fruit firmness gave high significant increase in treated trees with rock phosphate, Bacillus subtilis $\mathrm{AC}_{2}$ and sprayed with vitamin $C$. While, the least ones were found with the interactions between rock phosphate with (Enterobacter aerogenes $\mathrm{ECu}_{3} \mathrm{X}$ Bacillus subtilis $\mathrm{AC}_{2}$ ) and Vitamin $\mathrm{E}$ in both seasons. Regarding the interaction effect between phosphate sources and antioxidant applications, Table (3) clears that the interaction effect between Pentoxide phosphate and sprayed with vitamin $\mathrm{C}$, caused high significant increment in fruit firmness in both season. While, control treatment gave the least ones, the other interactions came in between.

\subsection{Flesh thickness:}

With regard to the interaction effect between Rock phosphate, phosphate solubilizing bacteria and antioxidant treatments, Table (4) reveals that in both seasons treated trees with rock phosphate 
with adding Bacillus subtilis $\mathrm{AC}_{2}$ and sprayed with $H$. sabdariffa extract gave the highest increase in flesh thickness (2.20 and $2.89 \mathrm{~cm}$ ) in both seasons. While, trees which treated with rock phosphate under Enterobacter aerogenes $\mathrm{ECu}_{3}$ and sprayed with vitamin $\mathrm{E}$ gave the least ones in flesh thickness in 2009 and 2010 seasons. The other treatments came in between.

Concerning, the interaction effect between phosphate sources and antioxidant applications, the interaction effect between phosphoric acid and sprayed with $H$. sabdariffa extract, proved to be the most effective treatment in flesh thickness in both Seasons. While, control treatment gave the least ones, in this respect. The other interaction treatments came in between.

\subsection{Flesh weight:}

As for the interaction effect between rock phosphate, phosphate solubilizing bacteria and antioxidant treatments, data in Table (4) revealed that treated trees with rock phosphate, Bacillus subtilis $\mathrm{AC}_{2}$ and sprayed with $H$. sabdariffa extract gave the highest increase in flesh weight (62.78 and $67.97 \mathrm{~g}$ ) in 2009 \& 2010 seasons, respectively. While, the least ones were found with the interactions between rock phosphate with Enterobacter aerogenes ECu3 and Vitamin E. The other interaction treatments came in between. Table (4) revealed that, in both seasons the interaction effect between phosphoric acid and sprayed with $H$. sabdariffa extract, gave the highest values of flesh weight (69.60 and $103.4 \mathrm{~g})$. On the contrary, the least ones were found in the control treatment, during both seasons. The other treatments came in between.

\subsection{Stone weight:}

With regard to the interaction effect between rock phosphate, phosphate solubilizing bacteria and antioxidant treatments, Table (4) clears that in both seasons treated trees with rock phosphate with adding Bacillus subtilis $\mathrm{AC}_{2}$ and sprayed with $H$. sabdariffa extract caused high significant increment in stone weight (10.33 and $11.23 \mathrm{~g})$. While, trees treated with rock phosphate under Enterobacter aerogenes $\mathrm{ECu} 3$ and sprayed with vitamin E gave the least ones in 2009 season.

On the other hand, trees treated with rock phosphate under Enterobacter aerogenes $\mathrm{ECu}_{3}$ and sprayed with $H$. sabdariffa extract gave the least value in stone weight in 2010 season. The other treatments came in between. Regarding, the interaction effect between phosphate sources and antioxidant applications, Table (4) showed that the interaction effect between phosphoric acid and sprayed with $H$. sabdariffa extract, gave the highest values of stone weight in both seasons (10.45 and $11.82 \mathrm{~g})$.While, the least ones were observed in control treatment, during both seasons.

\subsection{Flesh stone ratio:}

As for the interaction effect between rock phosphate, phosphate solubilizing bacteria and antioxidant treatments, data in Table (4) reveal that flesh: Stone ratio generally ranged from 5.22 to 6.08 in the first season and from 5.56 to 6.05 in the second one.

The least values $(5.22 \& 5.56)$ in the two seasons were recorded by the interactions between rock phosphate with Enterobacter aerogenes ECu3 and sprayed with Vitamin E. While, the highest ones (6.05\& 6.08) came from the interactions between rock phosphates, Bacillus subtilis $\mathrm{AC}_{2}$ and sprayed with $H$. sabdariffa extract during both seasons (Table 4).

Concerning, the interaction effect between phosphate sources and antioxidant applications, Table (4) revealed that the interaction effect between phosphoric acid 
Table (4): Effect of phosphate sources and /or phosphate solubilizing bacteria under antioxidant applications on flesh thickness, flesh weight, stone weight and flesh: stone ratio of 'EarliGrande' peach trees during 2009 and 2010 seasons.

\begin{tabular}{|c|c|c|c|c|c|c|c|c|c|}
\hline \multirow[t]{2}{*}{ Treatment } & \multirow[t]{2}{*}{$\begin{array}{l}\text { Antioxidant } \\
\text { application }\end{array}$} & \multicolumn{2}{|c|}{$\begin{array}{l}\text { Flesh thickness } \\
\text { (cm) }\end{array}$} & \multicolumn{2}{|c|}{$\begin{array}{l}\text { Flesh weight } \\
\text { (g) }\end{array}$} & \multicolumn{2}{|c|}{$\begin{array}{c}\text { Stone weight } \\
\text { (g) }\end{array}$} & \multicolumn{2}{|c|}{ Flesh : stone ratio } \\
\hline & & 2009 & 2010 & 2009 & 2010 & 2009 & 2010 & 2009 & 2010 \\
\hline \multicolumn{10}{|c|}{ 1. Effect of phosphate solubilizing bacteria and antioxidants application } \\
\hline \multirow[t]{3}{*}{ E. aerogenes } & $\begin{array}{l}\text { Hibiscus } \\
\text { sabdariffa } *\end{array}$ & $2.02^{\mathrm{b}}$ & $2.75^{\mathrm{bc}}$ & $57.00^{\mathrm{c}}$ & $60.11^{\mathrm{e}}$ & $9.14^{\mathrm{d}}$ & $10.01^{\mathrm{d}}$ & $5.54^{\mathrm{C}}$ & $6.01^{\mathrm{a}}$ \\
\hline & Vitamin $\mathbf{C}$. & $1.99^{\mathrm{bc}}$ & $2.72^{\mathrm{bc}}$ & $52.78^{\mathrm{e}}$ & $61.15^{\mathrm{cde}}$ & $9.93^{\mathrm{bc}}$ & $10.84^{\mathrm{bc}}$ & $5.32^{\mathrm{d}}$ & $5.65^{\mathrm{cd}}$ \\
\hline & Vitamin E. & $1.84^{\mathrm{d}}$ & $2.55^{\mathrm{d}}$ & $46.37^{\mathrm{g}}$ & $57.83^{\mathrm{f}}$ & $8.88^{\mathrm{e}}$ & $10.44^{\text {cd }}$ & $5.22^{\mathrm{e}}$ & $5.56^{\mathrm{d}}$ \\
\hline \multirow[t]{3}{*}{ B. subtilis } & $\begin{array}{l}\text { Hibiscus } \\
\text { sabdariffa * }\end{array}$ & $2.20^{\mathrm{a}}$ & $2.89^{\mathrm{a}}$ & $62.78^{\mathrm{a}}$ & $67.97^{\mathrm{a}}$ & $10.33^{\mathrm{a}}$ & $11.23^{\mathrm{a}}$ & $6.08^{a}$ & $6.05^{\mathrm{a}}$ \\
\hline & Vitamin C. & $2.07^{\mathrm{ab}}$ & $2.80^{\mathrm{abc}}$ & $56.38^{\mathrm{cd}}$ & $65.48^{\mathrm{b}}$ & $10.24^{\mathrm{abc}}$ & $11.10^{\mathrm{b}}$ & $5.52^{c}$ & $5.90^{\mathrm{ab}}$ \\
\hline & Vitamin E. & $1.94^{\mathrm{c}}$ & $2.66^{\mathrm{c}}$ & $50.28^{\mathrm{f}}$ & $65.00^{\text {bcd }}$ & $10.29^{\mathrm{a}}$ & $11.18^{\mathrm{a}}$ & $5.55^{\mathrm{c}}$ & $5.8^{\mathrm{bc}}$ \\
\hline \multirow{3}{*}{$\begin{array}{l}\text { E. aerogenes } \\
x \text { B. subtilis }\end{array}$} & $\begin{array}{l}\text { Hibiscus } \\
\text { sabdariffa * }\end{array}$ & $2.18^{\mathrm{a}}$ & $2.86^{\mathrm{ab}}$ & $60.99^{\mathrm{b}}$ & $65.32^{\mathrm{bc}}$ & $10.27^{\mathrm{ab}}$ & $11.15^{\mathrm{ab}}$ & $5.97^{a b}$ & $5.86^{\mathrm{abc}}$ \\
\hline & Vitamin C. & $2.07^{\mathrm{ab}}$ & $2.80^{\mathrm{abc}}$ & $55.43^{d}$ & $63.52^{\text {cd }}$ & $9.50^{\mathrm{c}}$ & $10.85^{\mathrm{bc}}$ & $5.84^{\mathrm{b}}$ & $5.87^{\mathrm{abc}}$ \\
\hline & Vitamin E. & $1.95^{\mathrm{c}}$ & $2.67^{\mathrm{c}}$ & $50.26^{\mathrm{f}}$ & $60.68^{\mathrm{de}}$ & $9.48^{\mathrm{c}}$ & $10.63^{\mathrm{bcd}}$ & $5.41^{\mathrm{cd}}$ & $5.71^{\mathrm{bcd}}$ \\
\hline \multicolumn{10}{|c|}{ 2. Effect of phosphate sourses and antioxidants application } \\
\hline \multirow[t]{3}{*}{ Control } & $\begin{array}{l}\text { Hibiscus } \\
\text { sabdariffa }\end{array}$ & $1.977^{\text {ghi }}$ & $2.197^{\mathrm{h}}$ & $44.07^{\text {gh }}$ & $64.30^{\mathrm{e}}$ & $7.700^{\mathrm{fg}}$ & $8.750^{\mathrm{de}}$ & $5.723^{\mathrm{a}-\mathrm{d}}$ & $6.383^{\text {de }}$ \\
\hline & Vitamin $\mathbf{C}$. & $1.943^{\text {hi }}$ & $2.257^{\text {gh }}$ & $41.99^{\mathrm{gh}}$ & $63.48^{\mathrm{e}}$ & $7.690^{\mathrm{fg}}$ & 8.407 de & $5.460^{\mathrm{bcd}}$ & $6.677^{\mathrm{b}-\mathrm{e}}$ \\
\hline & Vitamin E. & $1.900^{\mathrm{i}}$ & $2.133^{\mathrm{h}}$ & $37.32^{\mathrm{h}}$ & $55.76^{\mathrm{e}}$ & $7.543^{\mathrm{g}}$ & $7.993^{\mathrm{e}}$ & $4.967^{\mathrm{d}}$ & $5.997 \mathrm{e}$ \\
\hline \multirow[t]{3}{*}{$\begin{array}{l}\text { Rock } \\
\text { Phosphate }\end{array}$} & $\begin{array}{l}\text { Hibiscus } \\
\text { sabdariffa * }\end{array}$ & $2.280^{\mathrm{ab}}$ & $2.490^{\text {def }}$ & $57.53^{\text {bcd }}$ & $74.55^{\text {cde }}$ & $9.103^{\text {cde }}$ & $9.797^{\text {b-e }}$ & $6.317^{\mathrm{abc}}$ & $\underset{\text { cde }}{6.613}$ \\
\hline & Vitamin $\mathbf{C}$. & $2.243^{\mathrm{abc}}$ & $2.380^{\mathrm{fg}}$ & $54.62^{\text {cde }}$ & $68.35^{\mathrm{de}}$ & $8.483^{\mathrm{d}-\mathrm{g}}$ & $9.007^{\text {cde }}$ & $6.440^{\mathrm{ab}}$ & $\underset{\text { cde }}{6.590}$ \\
\hline & Vitamin E. & $2.140^{\text {cde }}$ & $2.437^{\text {ef }}$ & $44.38^{\text {fgh }}$ & $74.17^{\text {cde }}$ & $8.553^{\mathrm{d}-\mathrm{g}}$ & $9.980^{\mathrm{a}-\mathrm{d}}$ & $5.193^{\mathrm{cd}}$ & $\underset{\text { cde }}{6.433}$ \\
\hline \multirow[t]{3}{*}{$\begin{array}{l}\text { Super } \\
\text { phosphate }\end{array}$} & $\begin{array}{l}\text { Hibiscus } \\
\text { sabdariffa }\end{array}$ & $2.207^{\text {bcd }}$ & $2.650^{\text {bcd }}$ & $50.23^{\mathrm{c}-\mathrm{g}}$ & $74.67^{\text {cde }}$ & $9.193^{\text {bcd }}$ & $10.10^{\mathrm{a}-\mathrm{d}}$ & $\underset{\text { bcd }}{5.463}$ & $6.397^{\mathrm{de}}$ \\
\hline & Vitamin C. & $2.063^{\mathrm{efg}}$ & $2.590^{\text {cde }}$ & $47.20^{\text {efg }}$ & $88.13^{\mathrm{abc}}$ & $8.747^{\mathrm{def}}$ & $10.82 \mathrm{abc}$ & $\underset{\text { bcd }}{5.403}$ & $7.147^{\mathrm{a}-\mathrm{d}}$ \\
\hline & Vitamin E. & $2.010^{\text {fgh }}$ & $2.557^{\mathrm{c}-\mathrm{f}}$ & $48.28^{\mathrm{d}-\mathrm{g}}$ & $68.95^{\mathrm{de}}$ & $8.613^{\mathrm{d}-\mathrm{g}}$ & $8.867 \mathrm{cde}$ & $5.607^{\text {a- }}$ & $6.777^{\mathrm{a}-\mathrm{e}}$ \\
\hline \multirow[t]{3}{*}{$\begin{array}{l}\text { Pentoxide } \\
\text { phosphate }\end{array}$} & $\begin{array}{l}\text { Hibiscus } \\
\text { sabdariffa * }\end{array}$ & $2.233 \mathrm{bc}$ & $2.723^{\mathrm{abc}}$ & 59.14 bc & $96.76^{\mathrm{ab}}$ & $9.527^{\mathrm{a}-\mathrm{d}}$ & $11.21 \mathrm{ab}$ & $\underset{\mathrm{abc}}{6.210}$ & $7.640^{a b}$ \\
\hline & Vitamin C. & $2.193^{\text {bcd }}$ & $2.657^{\text {bcd }}$ & $53.68^{\mathrm{c}-\mathrm{f}}$ & $91.00^{a b c}$ & $8.083^{\text {efg }}$ & $11.25^{\mathrm{ab}}$ & $6.643^{\mathrm{a}}$ & $7.103^{a-d}$ \\
\hline & Vitamin E. & $2.107^{\text {def }}$ & $2.503^{\mathrm{def}}$ & $46.18^{\mathrm{e}-\mathrm{h}}$ & $84.40^{\text {bcd }}$ & $8.067^{\text {efg }}$ & $10.06^{\mathrm{a}-\mathrm{d}}$ & $5.747^{\text {a- }}$ & $7.397^{\mathrm{abc}}$ \\
\hline \multirow[t]{3}{*}{$\begin{array}{l}\text { Phosphoric } \\
\text { Acid }\end{array}$} & $\begin{array}{l}\text { Hibiscus } \\
\text { sabdariffa * }\end{array}$ & $2.347^{\mathrm{a}}$ & $2.893^{\mathrm{a}}$ & $69.60^{\mathrm{a}}$ & $103.4^{\mathrm{a}}$ & $10.45^{\mathrm{a}}$ & $11.82^{\mathrm{a}}$ & $6.673^{\mathrm{a}}$ & $7.753^{\mathrm{a}}$ \\
\hline & Vitamin C. & $2.303^{a b}$ & $2.787^{\mathrm{ab}}$ & $64.33^{\mathrm{ab}}$ & $99.10^{\mathrm{ab}}$ & $9.897^{\mathrm{abc}}$ & $11.47^{\mathrm{ab}}$ & $\underset{\mathrm{ab}}{6.503}$ & $7.643^{a b}$ \\
\hline & Vitamin E. & $2.273^{a b}$ & $2.783^{\mathrm{ab}}$ & $58.25^{\mathrm{bc}}$ & $92.52 \mathrm{abc}$ & $10.23^{\mathrm{ab}}$ & $11.03^{\mathrm{ab}}$ & $5.703^{a-}$ & $\begin{array}{c}7.397 \\
\text { abc }\end{array}$ \\
\hline
\end{tabular}

Means followed by the same letter(s) within each column are not significantly different at the 0.05 level, according to Duncan's multiple range test.

* Aqueous extract of Roselle plant Hibiscus sabdarffa other interaction treatments came in between. 
and sprayed with $H$. sabdariffa extract, proved to be the most effective on flesh: Stone ratio in both seasons. While, the control treatment gave the least ones.

The other treatments came in between. The improvement occurring in vegetative growth and leaf nutrient contents certainly reflected their effect on improving yield as well as fruit weight, fruit volume and flesh weight.

Another interpretation of the positive effect of phosphorous sources, solubilizing bacterium and antioxidant application are the role of free $\mathrm{N}, \mathrm{P}$ and $\mathrm{K}$ in producing adequate amounts of growth regulators, improving availability of nutrients which promoted the vegetative growth to go forward and then affect yield.

In addition, the beneficial effect of phosphate sources and $p$ solubilizing bacteria on enhancing soil fertility and the uptake of different nutrients as well as adding antioxidants surely reflected on stimulating growth characters and nutritional status of the peach trees in favor of producing more fruits and yield (ElKhawaga, 2011).

\section{Fruit chemical parameters:}

\subsection{TSS:}

Data in Table (5) reveal that the highest increase in TSS in both seasons were observed in trees treated with rock phosphate with adding Bacillus subtilis $\mathrm{AC}_{2}$ and sprayed with $H$. sabdariffa extract (9.39 and 10.23). While, the least ones were found with trees treated with rock phosphate under Enterobacter aerogenes $\mathrm{ECu}_{3}$ and sprayed with vitamin E.The other treatments came in between. Similar results were obtained by Kassem et al. (2010) who demonstrated that, ascorbic plus citric acids increased fruit weight, TSS, total sugars, reducing sugars, carotene and V.C contents and decreased fruit acidity and tannin contents as compared with untreated treatments.

Table (5) reveal that the interaction effect between phosphoric acid and sprayed with $H$. sabdariffa extract, gave the highest values of T.S.S in both seasons (10.45 and 11.82). While, the least ones were found in control treatment, during both seasons. The other interaction came in between.

\subsection{Acidity:}

Data in Table (5) reveal that treated trees with rock phosphate, Enterobacter aerogenes $\mathrm{ECu}_{3}$ and sprayed with vitamin $E$ caused high significant in Acidity in both seasons. While, the least ones were found with the interactions between rock phosphates with Enterobacter aerogenes $\mathrm{ECu}_{3} \times$ Bacillus subtilis $\mathrm{AC}_{2}$ and sprayed with vitamin $\mathrm{C}$ during both seasons.

The other treatments came in between. Similar results were obtained by Kassem et al., (2010) who demonstrated that, ascorbic plus citric acids increased fruit weight, TSS, total sugars, reducing sugars, carotene and Vitamin $\mathrm{C}$ contents and decreased fruit acidity and tannin (Ta) contents as compared with the control.

\subsection{Vitamin C:}

Table (5) reveal that treated trees with rock phosphate, Enterobacter aerogenes $\mathrm{ECu} 3 \times$ Bacillus subtilis $\mathrm{AC}_{2}$ and sprayed with vitamin $\mathrm{C}$ gave the highest increase in Vit.C (9.54 and 9.32) in 2009\&2010 seasons respectively. While, the least ones were found with the interactions between rock phosphates with Enterobacter aerogenes $\mathrm{ECu}_{3}$ and sprayed with vitamin $\mathrm{E}$ in Vit. $\mathrm{C}$ in both seasons.

In the mean time Table (5) reveal that the interaction effect between Pentoxide phosphate and sprayed with vitamin $\mathrm{C}$, gave the highest values of Vit. $\mathrm{C}$ in both seasons. The least ones were given in control treatment, during both seasons. 
Table (5): Effect of phosphate sources and / or phosphate solubilizing bacteria under antioxidant applications on total soluble solids, acidity, vitamin $C$ content and fruit moisture content of 'Earli Grande' peach trees during 2009 and 2010 seasons.

\begin{tabular}{|c|c|c|c|c|c|c|c|c|c|}
\hline \multirow[t]{2}{*}{ Treatment } & \multirow[t]{2}{*}{$\begin{array}{l}\text { Antioxidant } \\
\text { application }\end{array}$} & \multicolumn{2}{|c|}{$\begin{array}{l}\text { TSS } \\
(\%)\end{array}$} & \multicolumn{2}{|c|}{$\begin{array}{c}\text { Acidity } \\
(\%)\end{array}$} & \multicolumn{2}{|c|}{$\begin{array}{c}\text { Vit.C } \\
\text { mgeq. Ascorbic } \\
\text { Acid }\end{array}$} & \multicolumn{2}{|c|}{$\begin{array}{c}\text { Moisture content } \\
(\%)\end{array}$} \\
\hline & & 2009 & 2010 & 2009 & 2010 & 2009 & 2010 & 2009 & 2010 \\
\hline \multirow{5}{*}{ E. aerogenes } & \multicolumn{9}{|c|}{ 1.Effect of phosphate solubilizing bacteria and antioxidants application } \\
\hline & Hibiscus sabdariffa * & $9.02^{\mathrm{ab}}$ & $9.98^{\mathrm{abc}}$ & $0.12^{\mathrm{ab}}$ & $0.1^{\mathrm{b}}$ & $7.33^{\text {cde }}$ & $8.40^{\mathrm{c}}$ & $64.47^{\mathrm{f}}$ & $67.96^{\text {cde }}$ \\
\hline & Vitamin C. & $8.69^{\text {cd }}$ & $9.50^{\mathrm{cd}}$ & $0.10^{\mathrm{abc}}$ & $0.14^{\mathrm{ab}}$ & $7.15^{\mathrm{de}}$ & $8.48^{\mathrm{c}}$ & $66.73^{\mathrm{e}}$ & $68.32^{\text {cd }}$ \\
\hline & Vitamin E. & $7.92^{\mathrm{e}}$ & $8.73^{\mathrm{e}}$ & $0.16^{\mathrm{a}}$ & $0.18^{\mathrm{a}}$ & $6.05^{\mathrm{f}}$ & $7.01^{\mathrm{e}}$ & $63.22^{\mathrm{g}}$ & $66.57^{\circ}$ \\
\hline & Hibiscus sabdariffa * & $9.39^{\mathrm{a}}$ & $10.23^{\mathrm{a}}$ & $0.11^{\mathrm{abc}}$ & $0.12^{\mathrm{b}}$ & $8.29^{\text {bcd }}$ & $8.92^{\mathrm{abc}}$ & $69.18^{a}$ & $71.71^{\mathrm{a}}$ \\
\hline B. subtilis & Vitamin C. & $8.96^{\mathrm{abc}}$ & $10.01^{\mathrm{ab}}$ & $0.09^{\mathrm{bc}}$ & $0.08^{\mathrm{cd}}$ & $8.55^{\mathrm{b}}$ & $9.06^{\mathrm{ab}}$ & $67.75 \mathrm{c}$ & $69.86^{\mathrm{bc}}$ \\
\hline \multirow{4}{*}{$\begin{array}{l}\text { E. aerogenes } \\
x \text { B. subtilis }\end{array}$} & Vitamin E. & $8.76^{\text {bcd }}$ & $9.87^{\mathrm{bc}}$ & $0.13^{\mathrm{ab}}$ & $0.15^{\mathrm{ab}}$ & $6.32 \mathrm{e}$ & $7.81^{\mathrm{de}}$ & $63.36^{\mathrm{fg}}$ & $68.95^{\mathrm{c}}$ \\
\hline & Hibiscus sabdariffa * & $9.33^{\mathrm{a}}$ & $9.98^{\mathrm{abc}}$ & $0.08^{\mathrm{bc}}$ & $0.07^{\mathrm{d}}$ & $8.47^{\mathrm{bc}}$ & $8.84^{\mathrm{bc}}$ & $68.53^{b}$ & $71.03^{\mathrm{ab}}$ \\
\hline & Vitamin C. & $8.81^{b c}$ & $9.77^{\mathrm{bcd}}$ & $0.07^{\mathrm{c}}$ & $0.07^{\mathrm{d}}$ & $9.54^{\mathrm{a}}$ & $9.32^{\mathrm{a}}$ & $67.19^{d}$ & $70.38^{b}$ \\
\hline & Vitamin E. & $8.52^{\mathrm{d}}$ & $8.91^{\mathrm{d}}$ & $0.10^{\mathrm{abc}}$ & $0.09 \mathrm{c}$ & $7.68^{\mathrm{cd}}$ & $7.88^{\mathrm{d}}$ & $63.52^{\mathrm{f}}$ & $67.62^{\mathrm{de}}$ \\
\hline \multirow{4}{*}{ Control } & \multicolumn{7}{|c|}{ 2.Effect of phosphate sourses and antioxidants application } & & \\
\hline & Hibiscus sabdariffa * & $8.337^{\mathrm{efg}}$ & $8.243^{\mathrm{fg}}$ & $0.547^{\mathrm{b}}$ & $0.653^{b}$ & $5.03^{\mathrm{h}}$ & $5.590^{\mathrm{i}}$ & $61.43^{\mathrm{bc}}$ & $66.46^{\mathrm{fg}}$ \\
\hline & Vitamin C. & $7.463^{\text {ghi }}$ & $8.297^{\mathrm{fg}}$ & $0.373^{\mathrm{g}}$ & $0.547^{\mathrm{g}}$ & $5.333^{\text {gh }}$ & $6.760^{\text {ghi }}$ & $59.64^{\mathrm{c}}$ & $64.02^{\text {hi }}$ \\
\hline & Vitamin E. & $6.597^{\mathrm{i}}$ & $7.947^{\mathrm{g}}$ & $0.587^{\mathrm{a}}$ & $0.667^{\mathrm{a}}$ & $4.767^{\mathrm{h}}$ & $5.333^{j}$ & $52.87^{\mathrm{d}}$ & $63.04^{\mathrm{i}}$ \\
\hline \multirow{6}{*}{$\begin{array}{l}\text { Super } \\
\text { phosphate }\end{array}$} & Hibiscus sabdariffa * & $8.790^{\text {def }}$ & $9.667^{\mathrm{de}}$ & $0.333^{\mathrm{h}}$ & $0.600^{\mathrm{e}}$ & $9.233^{\mathrm{a}-\mathrm{d}}$ & $7.167^{\text {fgh }}$ & $65.8^{\mathrm{ab}}$ & $67.37^{\mathrm{ef}}$ \\
\hline & Vitamin C. & $7.820^{\mathrm{fgh}}$ & $9.937^{\text {cd }}$ & $0.253^{\mathrm{k}}$ & $0.533^{h}$ & $9.383^{\mathrm{a}-\mathrm{d}}$ & $8.490^{\mathrm{def}}$ & $63.90^{\mathrm{abc}}$ & $65.38^{\text {fgh }}$ \\
\hline & Vitamin E. & $6.953^{\mathrm{hi}}$ & $9.047^{\mathrm{ef}}$ & $0.467 \mathrm{c}$ & $0.613^{\mathrm{d}}$ & $7.167^{\mathrm{ef}}$ & $6.333^{\text {hij }}$ & $63.00^{\mathrm{abc}}$ & $64.87^{\text {ghi }}$ \\
\hline & Hibiscus sabdariffa * & $9.377^{\mathrm{a}-\mathrm{d}}$ & $10.13^{\mathrm{cd}}$ & $0.413^{\mathrm{d}}$ & $0.507^{\mathrm{j}}$ & $8.267^{\mathrm{c}-\mathrm{f}}$ & $7.950^{\text {efg }}$ & $64.70^{\mathrm{abc}}$ & $70.05^{\mathrm{cd}}$ \\
\hline & Vitamin C. & $8.967^{\text {cde }}$ & $10.12^{\mathrm{cd}}$ & $0.333^{h}$ & $0.320^{\mathrm{m}}$ & $7.733^{\text {def }}$ & $9.770^{\mathrm{a}-\mathrm{d}}$ & $63.55^{\mathrm{abc}}$ & $69.62^{\mathrm{cd}}$ \\
\hline & Vitamin E. & $8.720^{\text {def }}$ & $10.04^{\mathrm{cd}}$ & $0.387^{\mathrm{f}}$ & $0.440^{\mathrm{k}}$ & $6.860^{\mathrm{fg}}$ & $6.933^{\text {ghi }}$ & $59.54^{\mathrm{c}}$ & $66.68^{\mathrm{fg}}$ \\
\hline \multirow{3}{*}{$\begin{array}{l}\text { Pentoxide } \\
\text { phosphate }\end{array}$} & Hibiscus sabdariffa * & $9.920^{\mathrm{abc}}$ & $10.03^{\mathrm{cd}}$ & $0.280^{\mathrm{j}}$ & $0.293^{n}$ & $10.23^{\mathrm{ab}}$ & $10.92^{\mathrm{ab}}$ & $67.29^{\mathrm{a}}$ & $71.01^{\mathrm{abc}}$ \\
\hline & Vitamin C. & $9.080^{\mathrm{b}-\mathrm{e}}$ & $9.493^{\mathrm{de}}$ & $0.253^{\mathrm{k}}$ & $0.213^{\circ}$ & $10.93^{\mathrm{a}}$ & $11.19^{\mathrm{a}}$ & $65.06^{\mathrm{abc}}$ & $70.76^{\text {bcd }}$ \\
\hline & Vitamin E. & $8.400^{\mathrm{d}-\mathrm{g}}$ & $8.907^{\mathrm{ef}}$ & $0.320^{\mathrm{i}}$ & $0.400^{1}$ & $9.543^{\mathrm{abc}}$ & $9.663^{\text {bcd }}$ & $64.64^{\mathrm{abc}}$ & $68.84^{\mathrm{de}}$ \\
\hline \multirow{3}{*}{$\begin{array}{l}\text { Phosphoric } \\
\text { Acid }\end{array}$} & Hibiscus sabdariffa * & $10.10^{\mathrm{a}}$ & $11.69^{\mathrm{a}}$ & $0.333^{\mathrm{h}}$ & $0.587^{f}$ & $8.833^{\mathrm{b}-\mathrm{e}}$ & $10.29^{\mathrm{abc}}$ & $68.5^{\mathrm{a}}$ & $72.96^{\mathrm{a}}$ \\
\hline & Vitamin C. & $9.990^{\mathrm{ab}}$ & $11.28^{\mathrm{ab}}$ & $0.253^{\mathrm{k}}$ & $0.520^{\mathrm{i}}$ & $10.03^{\mathrm{abc}}$ & $10.57^{\mathrm{ab}}$ & $67.19^{\mathrm{a}}$ & $72.23^{\mathrm{ab}}$ \\
\hline & Vitamin E. & $9.083^{\mathrm{b}-\mathrm{e}}$ & $10.80^{\mathrm{bc}}$ & $0.400^{\mathrm{e}}$ & $0.627^{\mathrm{c}}$ & $7.733^{\text {def }}$ & $9.000^{\text {cde }}$ & $66.54^{\mathrm{ab}}$ & $69.95^{\mathrm{cd}}$ \\
\hline
\end{tabular}

Similar observations were reported by (Li et al. 2007).

\subsection{Moisture content:}

Table (5) reveal that treated trees with rock phosphate, Bacillus subtilis $\mathrm{AC}_{2}$ and sprayed with $H$. sabdariffa extract gave the highest significant increase in Vit. C $(68.53$ and $71.03 \%)$ in both seasons. While, the least ones were found with the interactions between rock phosphates with Enterobacter aerogenes $\mathrm{ECu}_{3}$ and sprayed with Vitamin $\mathrm{E}$ in Vit. $\mathrm{C}$ in both seasons.

The remained interaction treatments came in between. Similarly Table (5) show that the interaction effect between phosphoric acid and sprayed with $H$. sabdariffa extract, gave the highest values of moisture content in both seasons.

While, the least ones were found in control treatment and the other treatments came in between. Finally, it can be concluded that the increase in leaf nutrient contents, specially phosphorus leads to increase photo-synthesis and thereby increase the proportion of carbohydrates in the leaves and reflected in fruit chemical properties i.e., total soluble solids (TSS) and decrease total acidity (Stino et al. 2009).

Table (5) reveal that the interaction effect between control treatment with vitamin $\mathrm{E}$, gave the highest significant values of acidity in both seasons. While, 
the control treatment gave the least ones in 2009 and 2010 seasons and the other treatments came in between.

\section{REFERENCES}

AOAC. (1990). Official Methods of Analysis. $15^{\text {th }}$ ed., Association of Official Agriculture Chemists Washington D.C., USA.

Asea, P. E. A., Kucey, R. M. N. and Stewart, J. W. B. (1988). Inorganic phosphate solubilization by two Penicillium species in solution culture and soil. Soil Biol. Biochem., 20: 459-464.

Awasthi, R. P.; Bhutani, V. P.; Mankotia, M. S; Kith, N. S; and Dev, G. (1998). Potash improves to yield and quality of July Elberta peach. Better Crops Intern.12, 30

Chatzitheodorou, I. T; Sotiropoulos, T. E; and Mouhtaridou, G. I; (2004). Effect of nitrogen, phosphorous, potassium fertilization and manure on fruit yield and fruit quality of the peach cultivars "Spring Time" and "Red Haven". Agronomy research. 2 (2), 135- 143.

Claudia S. G.; Fidel T. V.; Ana E. O.; and José Á. G. (2012). Antioxidant properties and color of Hibiscus sabdariffa extracts. Cien. Inv. Agr. 39(1):79-90.

Duncan, B. D. (1955). Multiple Range and Multiple F-tests. Biometrics, 11: $1-42$.

El- Khawaga, A.S. (2012). Partial Replacement of Mineral N Fertilizers by Using Humic Acid And Spirulina. Platensis Algae Biofertilizer In Florida Prince Peach Orchards. Middle East Journal of Applied Sciences 1 (1): 5-10, 2011.

Gyaneshwar, P., Naresh, K. G. and Parekh, L. J. (1998). Cloning of mineral phosphate solubilizing genes from Synechocystis PCC 6803 P., Curr. Sci., 74: 1097-1099.

Ivanova, R., Bojinova, D. and Nedialkova, K. (2006). Rock Phosphate solubilization by soil bacteria, J. Uni. of Chemical Techn. and Metallurgy, 41 (3): 297-302.

Kassem H. A., Amal M. El-Kobbia, Hend A. Marzouk and Mohamed M. El- Sebaiey (2010). Effect of foliar sprays on fruit retention, quality and yield of Costata persimmon trees. Emir. J. Food Agric. 2010. 22 (4): 259-274.

Li J.; Wang Z.; Pang Z. Y.; Fang Q.; and Li Cheng B. (2007). Effects of spraying $\mathrm{KH} 2 \mathrm{PO} 4$ on leaf chlorophyll content, leaf weight and fruit quality of peach cultivars. Journal of Fruit Science. 2007. 24: 4, 533-536. 7 ref.

Piper, C. S. (1947). Soil and plant analysis. The University of Adelaide (Australia) pp: 59-74.

Russell, D. F. (1986): MSTATC Director, Crop and Soil Sciences Department, Michigan State University, Computer Program Package Version 2.10.

Sahain M. F.M., Elham Z. Abd El Motty, Mohamed H.El- Shiekh and Laila. F. Hagagg (2007). Effect of Some Biostimulant on Growth and fruiting of Anna Apple Trees In Newly Reclaimed Areas. Research Journal of Agriculture and Biological Sciences, 2007.3(5): 422-429.

Samah, Y.A.E., (2002). Effect of biofertilizer on yield and berry qualities of grapevines. M. Sc. Thesis. Fac. Agric., Mansoura Univ., Egypt.

Singh, C. and B.B. Sharma, (1993). Leaf nutrient composition of sweet orange as affected by combined use of bio and chemical fertilizers. South Indian Hort., 41: 131-134. 
Stino, R.G., A.T. Mohsen and M.A. Maksoud, (2009). Bio-Organic fertilization and its impact on apricot young trees in newly reclaimed soil. American - Eurasian J. Agric. And Environ. Sci., 6(1): 62-69.

Toro, M., Azcon, R. and Barea, J.M. (1997). Improvement of arbuscula mycorrhiza development by inoculation of soil with phosphatesolub- ilizing rhizobacteria to improve rock phosphate bioavailability ((sup32) P) and Nutrient Cycling. Appl. Environ. Microbiol., 63: 4408-4412.

Yang M. sheng (2010). The effects of Nongdage bio-fertilizer on peach growth output and quality. Chinese Agricultural Sc. Bulletin., 26(1): 130133.

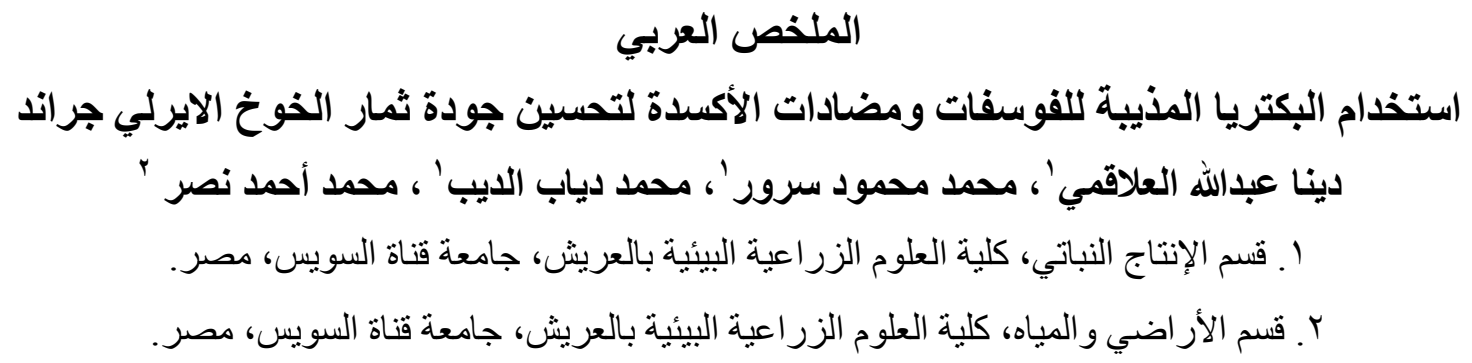

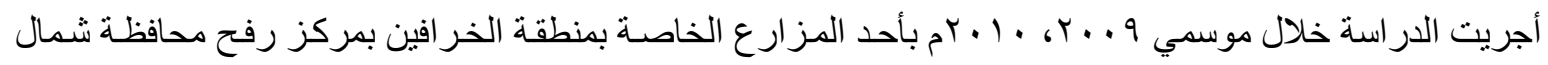
سيناء مصر، لدر اسة تأثير البكتريا المذيبة للفوسفات (Enterobacter aerogenes ECu منفرد، Eacillus subtilis

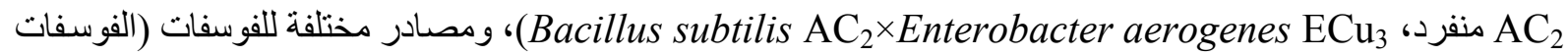
الصخري، وحمض الفوسفوريك، وخامس أكسيد الفوسفات والسوبر فوسفات)، مع الرش الورقاتعي ببعض مضـادادات الأكسدة (حض الاسكوربيك، فيتامين E ، و المستخلص المائي من الكركديه) على الخصـيائص الفيزيائية و الكيميائية و المحصدول

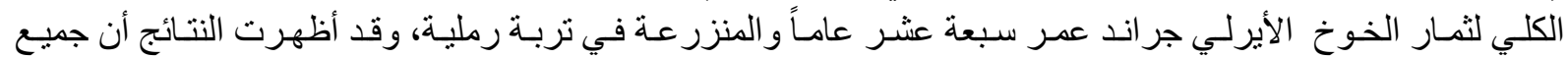

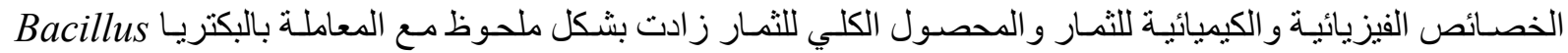
subtilis AC2 AC $_{2}$

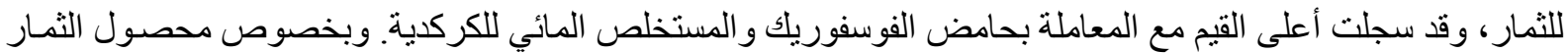

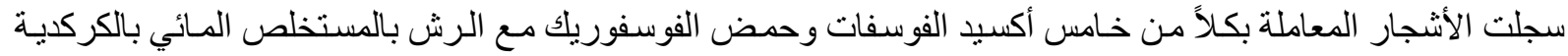

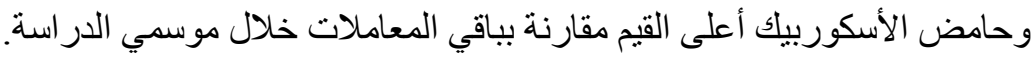
الكلمات الإسترشادية: البكتريا المذيبة للفوسفات، ومضادات الأكسدة، الجودة، الخوخ الايرلي جر اند.

أستاذ الفاكهة المساعدـ كلية العلوم الزر اعية البيئية بالعريش- جامعة قناة السويس.

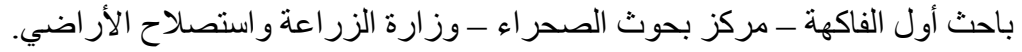

